NASA/TM-2011-217035

\title{
Demonstration of Multi-Gbps Data Rates at Ka-Band Using Software-Defined Modem and Broadband High Power Amplifier for Space Communications
}

Rainee N. Simons and Edwin G. Wintucky

Glenn Research Center, Cleveland, Ohio

David G. Landon, Jun Y. Sun, James S. Winn, Stephen Laraway, William K. McIntire, John L. Metz, and Francis J. Smith

L-3 Communication Systems-West, Salt Lake City, Utah 


\section{NASA STI Program . . . in Profile}

Since its founding, NASA has been dedicated to the advancement of aeronautics and space science. The NASA Scientific and Technical Information (STI) program plays a key part in helping NASA maintain this important role.

The NASA STI Program operates under the auspices of the Agency Chief Information Officer. It collects, organizes, provides for archiving, and disseminates NASA's STI. The NASA STI program provides access to the NASA Aeronautics and Space Database and its public interface, the NASA Technical Reports Server, thus providing one of the largest collections of aeronautical and space science STI in the world. Results are published in both non-NASA channels and by NASA in the NASA STI Report Series, which includes the following report types:

- TECHNICAL PUBLICATION. Reports of completed research or a major significant phase of research that present the results of NASA programs and include extensive data or theoretical analysis. Includes compilations of significant scientific and technical data and information deemed to be of continuing reference value. NASA counterpart of peer-reviewed formal professional papers but has less stringent limitations on manuscript length and extent of graphic presentations.

- TECHNICAL MEMORANDUM. Scientific and technical findings that are preliminary or of specialized interest, e.g., quick release reports, working papers, and bibliographies that contain minimal annotation. Does not contain extensive analysis.

- CONTRACTOR REPORT. Scientific and technical findings by NASA-sponsored contractors and grantees.
- CONFERENCE PUBLICATION. Collected papers from scientific and technical conferences, symposia, seminars, or other meetings sponsored or cosponsored by NASA.

- SPECIAL PUBLICATION. Scientific, technical, or historical information from NASA programs, projects, and missions, often concerned with subjects having substantial public interest.

- TECHNICAL TRANSLATION. Englishlanguage translations of foreign scientific and technical material pertinent to NASA's mission.

Specialized services also include creating custom thesauri, building customized databases, organizing and publishing research results.

For more information about the NASA STI program, see the following:

- Access the NASA STI program home page at http://www.sti.nasa.gov

- E-mail your question via the Internet to help@ sti.nasa.gov

- Fax your question to the NASA STI Help Desk at $443-757-5803$

- Telephone the NASA STI Help Desk at 443-757-5802

- Write to: NASA Center for AeroSpace Information (CASI) 7115 Standard Drive Hanover, MD 21076-1320 
NASA/TM-2011-217035

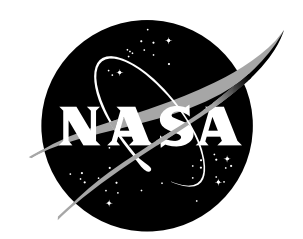

\section{Demonstration of Multi-Gbps Data Rates at Ka-Band Using Software-Defined Modem and Broadband High Power Amplifier for Space Communications}

Rainee N. Simons and Edwin G. Wintucky

Glenn Research Center, Cleveland, Ohio

David G. Landon, Jun Y. Sun, James S. Winn, Stephen Laraway, William K. McIntire, John L. Metz, and Francis J. Smith

L-3 Communication Systems-West, Salt Lake City, Utah

Prepared for the

International Microwave Symposium for 2011 (IMS2011)

sponsored by the Institute of Electrical and Electronics Engineers, Microwave Theory and Techniques Society (MTT-S)

Baltimore, Maryland, June 5-10, 2011

National Aeronautics and

Space Administration

Glenn Research Center

Cleveland, Ohio 44135 


\section{Acknowledgments}

This research was partially supported by the 2010 NASA Innovative Partnership Program Innovation Fund Award.

Trade names and trademarks are used in this report for identification only. Their usage does not constitute an official endorsement, either expressed or implied, by the National Aeronautics and Space Administration.

Level of Review: This material has been technically reviewed by technical management.

Available from

NASA Center for Aerospace Information 7115 Standard Drive

Hanover, MD 21076-1320
National Technical Information Service 5301 Shawnee Road Alexandria, VA 22312

Available electronically at http://www.sti.nasa.gov 


\title{
Demonstration of Multi-Gbps Data Rates at Ka-Band Using Software- Defined Modem and Broadband High Power Amplifier for Space Communications
}

\author{
Rainee N. Simons and Edwin G. Wintucky \\ National Aeronautics and Space Administration \\ Glenn Research Center \\ Cleveland, Ohio 44135 \\ David G. Landon, Jun Y. Sun, James S. Winn, Stephen Laraway, \\ William K. McIntire, John L. Metz, and Francis J. Smith \\ L-3 Communication Systems-West \\ Salt Lake City, Utah 84116
}

\begin{abstract}
The paper presents the first ever research and experimental results regarding the combination of a software-defined multiGbps modem and a broadband high power space amplifier when tested with an extended form of the industry standard DVB-S2 and LDPC rate 9/10 FEC codec. The modem supports waveforms including QPSK, 8-PSK, 16-APSK, 32-APSK, 64-APSK, and 128-QAM. The broadband high power amplifier is a space qualified traveling-wave tube (TWT), which has a passband greater than $3 \mathrm{GHz}$ at $33 \mathrm{GHz}$, output power of $200 \mathrm{~W}$ and efficiency greater than 60 percent. The modem and the TWTA together enabled an unprecedented data rate at $20 \mathrm{Gbps}$ with low BER of $10^{-9}$. The presented results include a plot of the received waveform constellation, BER vs. $\mathrm{E}_{\mathrm{b}} / \mathrm{N}_{0}$ and implementation loss for each of the modulation types tested. The above results when included in an RF link budget analysis show that NASA's payload data rate can be increased by at least an order of magnitude ( $>10 \mathrm{X})$ over current state-of-practice, limited only by the spacecraft EIRP, ground receiver $\mathrm{G} / \mathrm{T}$, range, and available spectrum or bandwidth.
\end{abstract}

\section{Introduction}

NASA is in need of a versatile, higher data rate integrated space communications network to provide services to space flight missions located throughout the solar system (Ref. 1). The driving requirements for the network are quite broad, covering space based navigation and communications for manned and robotic missions from near-Earth to deep space, all with emphasis on higher data rates in the Gbps range. The justification for Gbps data rates is closely linked to the capabilities of remote spacecraft sensors, which are quickly outstripping the ability of current data links to rapidly move the sensor information back to Earth (Ref. 2). Four data links that are potential elements of NASA's integrated space communications network are: satellites in low Earth orbit (LEO), lunar relay satellites (LRS), spacecrafts stationed at the second Lagrangian point (L2), and spacecrafts in deep space (DS). In addition, Gbps data rate technology is useful for fixed, mobile, broadcast, broadband and commercial Earth imaging satellite services (Ref. 3).

In this paper, we present experimental results, which can enhance the RF communications capability of NASA's spacecraft-to-Earth data links identified above. We demonstrated in a laboratory setting very high data rates on the order of multi-Gbps (20 Gbps) at Ka-band frequencies using software-defined modems (SDMs), bandwidth efficient modulation (BEM) techniques (PSK, APSK, and QAM) and a broadband high efficiency high power space amplifier. To the best of our knowledge this is the first ever demonstration of such high data rates through a high power space amplifier at Ka-band frequency. The presented results include a plot of the received waveform constellation, BER vs. $\mathrm{E}_{\mathrm{b}} / \mathrm{N}_{0}$, and implementation loss for each of the modulation types investigated. These results, when included in an RF link budget analysis, show that the data rate of the above links can be enhanced by an order of magnitude (>10X) over current state-of-practice. By simultaneously using RHCP and LHCP for transmission, the data rate can be doubled $(\sim 20 \mathrm{X})$. If a dual-polarization/dual-beam system is used, the data rate can be quadrupled ( 40X).

\section{Enabling Technologies}

The two technologies, high-speed software-defined modems and Ka-band broadband high efficiency high power space amplifiers, are critical components in meeting the above goals of increasing user data rates. 


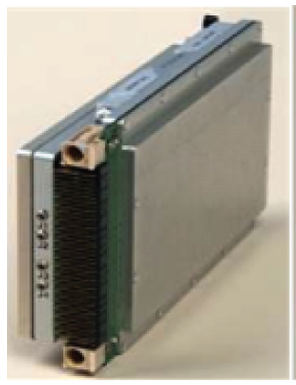

(a)

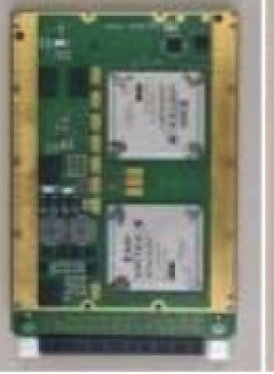

(b)

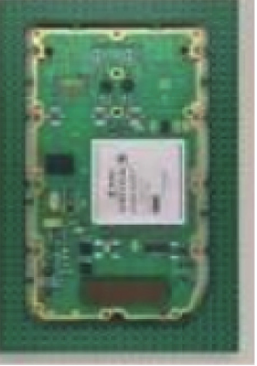

(c)
Figure 1.-L-3 CSW Gbps software-defined modem (SDM).

(a) The enclosed modem is 6 by 4 by $1.5 \mathrm{in}$. and contains (b) two digital cards and (c) mixed signal card with A/D and D/A converters. One module is used for transmission and one for reception.

\section{A. Software-Defined Modem (SDM)}

State-of-the-art mixed signal, fully software-defined modem (SDM) based on the latest field programmable gate array (FPGA) technology (Fig. 1) have been implemented, which currently support lower-order modulations (QPSK and 8-PSK) and are programmable for higher-order modulations (Ref. 4). In addition, an advanced modem breadboard consisting of laboratory test equipment and in-house developed software has also been implemented, which can support 16-APSK, 32-APSK, 64-APSK, and 128-QAM waveforms operating in real time while transmitting standard pseudo random bit stream (PRBS) test patterns (Ref. 4).

\section{B. Traveling-Wave Tube Amplifier (TWTA)}

Space TWTAs for near-Earth and deep space missions at $\mathrm{K}$-band and Ka-band frequencies are currently flying in space. Efficiencies of these amplifiers are in the range of 50 to 60 percent and the corresponding RF output power level is in the range of 35 to $200 \mathrm{~W}$. In References 5 and 6, examples of NASA space TWTAs and their RF performance characteristics including size and mass are presented. The typical design bandwidth has been $500 \mathrm{MHz}$, but these amplifiers perform well with bandwidths in excess of $3 \mathrm{GHz}$. The TWTA provides very high efficiency, high power, wide bandwidth, and good linearity. These characteristics, combined with pre-compensation in the SDM and in the advanced modem breadboard, allow dense higher-order waveform constellations to be supported with small implementation losses.

\section{Waveform Design and Implementation}

The waveforms investigated include the digital video broadcasting-satellite, second-generation (DVB-S2), family. Details of the modulation, constellation mapping, interleaving, and encoding for QPSK, 8-PSK, 16-APSK, and 32-APSK modes are available in Reference 7. We extend the DVB-S2 modulation suite to higher-order modulation types and use the 64-APSK constellation given in Reference 8 and the 128-QAM cross II constellation from Reference 9. The forward error correction (FEC) employed in our work is the low-density parity-check (LDPC) rate 9/10 code described by the European Telecommunications Standard Institute (ETSI) (Ref. 7).

\section{A. Using Software-Defined Modem}

The waveforms are implemented in the FPGA-based SDM shown in Figure 1. The modem has a transmit and a receive module. The transmit module has an I/Q-sampler and a twostage X-band/Ka-band up-converter and the receive module has a two-stage X-band/Ka-band down-converter as analog interfaces. The SDM supports QPSK and 8-PSK waveforms. Each also supports continuously configurable data rates (and bandwidth) via digitally interpolated symbol timing and a fixed sample clock.

\section{B. Using Advanced Modem Breadboard}

The advanced modem breadboard consists of laboratory test equipment and in-house developed software that provides the capability to test waveforms over actual channels. The advanced modem breadboard uses the same digital algorithms as used in the SDM at the same symbol rate and bandwidth at any data rate and modulation up to $20 \mathrm{Gbps}$. The advanced modem is used to test 16-APSK, 32-APSK, 64-APSK, and 128-QAM waveforms.

\section{Distortion Mitigation}

To achieve high data rates, the advanced modem breadboard includes non-linear pre-compensation for the TWTA AM/AM and AM/PM, as well as compensation for the I/Q modulator distortions. Figure 2 shows the output spectrum of the TWTA, given a frequency-flat $3 \mathrm{GHz}$ input signal, without and with pre-compensation. Notice that with precompensation the signal is flatter. 

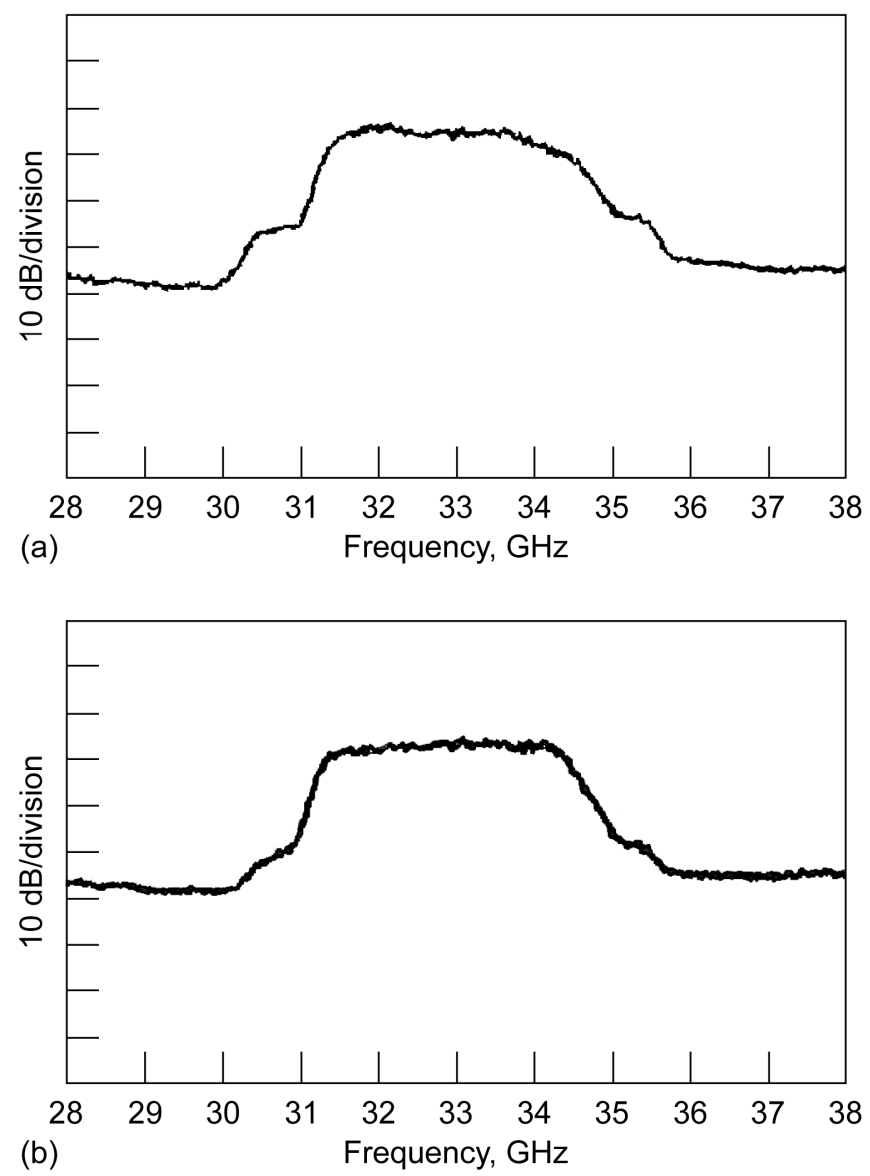

Figure 2.-Spectrum analyzer capture of the RF spectrum including that of the up- and down-conversion and the TWTA: (a) Without. (b) With linear pre-compensation.

\section{Experimental Setup}

The TWTA output power and phase as a function of the input drive power was measured across the 31 to $35 \mathrm{GHz}$ band. For these measurements, the TWTA voltages and currents were set so that the saturated output power $\left(\mathrm{P}_{\mathrm{SAT}}\right)$ was $125 \mathrm{~W}$. Figure 3 shows the measured normalized output power and phase of the TWTA as a function of the input drive power at $\mathrm{f}_{0}=33 \mathrm{GHz}$. Supporting hardware was set up around the TWTA to match the IF of the modem to the Ka-band test channel. A system level block diagram of the experimental setup is shown in Figure 4. The advanced modem breadboard modulator is comprised of a personal computer (PC) hosting software that emulates a software-defined modulator, a Tektronix Arbitrary Waveform Generator and a Hittite Microwave I/Q Mixer. The advanced modem breadboard demodulator consists of a PC hosting software that emulates a software-defined demodulator and a Tektronix digital oscilloscope.

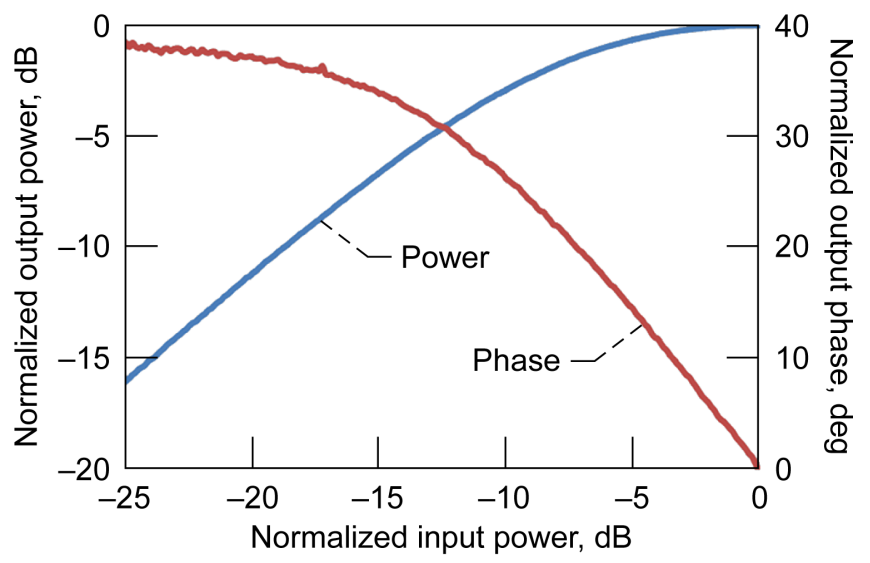

Figure 3.-Normalized output power and phase of the TWTA as a function of the input drive power at $\mathrm{f}_{0}=33 \mathrm{GHz}$. These parameters are needed for pre-compensation. $\mathrm{P}_{\text {sat }}=125 \mathrm{~W}$.

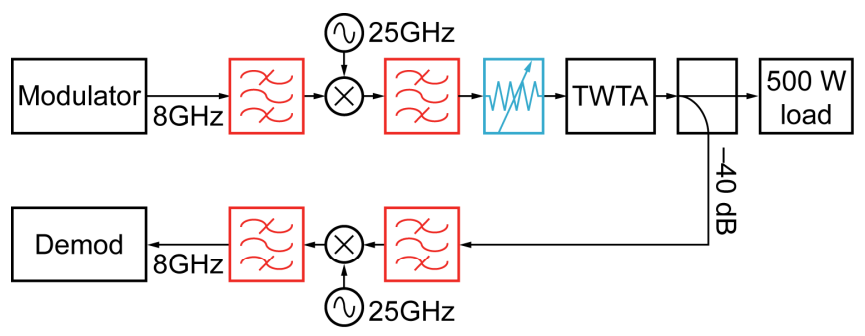

Figure 4.-System level block diagram of the experimental setup. The "Modulator" and "Demod" blocks shown represent either the software-defined modem or the advanced modem breadboard.

\section{Advanced Modem Performance Results}

Transmitting a modulated waveform through the TWTA and then demodulating the received waveform enabled an assessment of the waveform performance through the test channel at $33 \mathrm{GHz}$. In order to induce bit errors for the purpose of a BER measurement, the advanced modem breadboard demodulator digitally added generated pseudo noise at precisely controlled levels to the received A/D output samples. The implementation of the digital noise generator is based on the work of Marsaglia and Tsang (Ref. 10) on the Ziggurat method for generating random variables. Modulation schemes of QPSK, 8-PSK, 16-PSK, 32-APSK, 64-APSK, and 128-QAM were tested in conjunction with the DVB-S2 LDPC 9/10 FEC codec. 
TWTA BER performance: DVB-S2 LDPC 9/10

(code block size 64800 bits and decoder iteration count $=16$ )

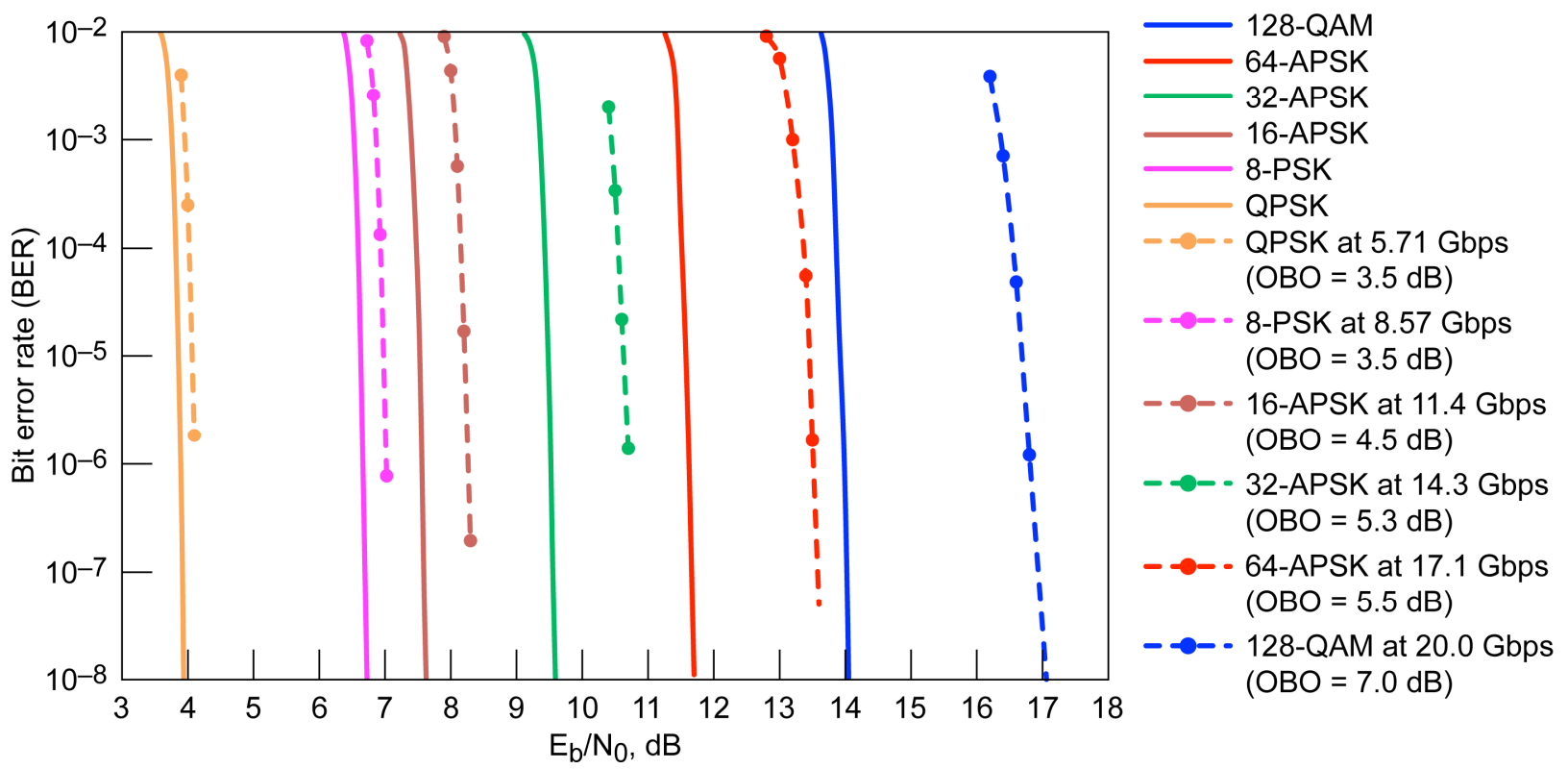

Figure 5.-BER versus $E_{b} / N_{0}$ for each of the modulation types tested with the DVB-S2 LDPC 9/10 codec. Solid line is a floating-point model and dotted line is measured data. The difference is the implementation loss, which is attributed to an underlying system noise floor due to quantization noise, thermal noise, and other types of distortion-induced noise and intermodulation products of the channel.

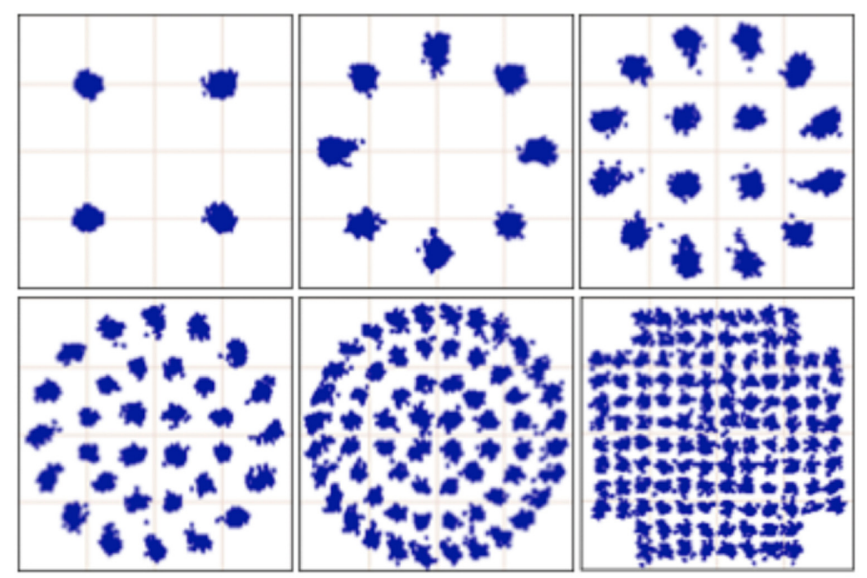

Figure 6.-Received constellation for QPSK, 8-PSK, 16-APSK, 32-APSK, 64-APSK, and 128-QAM at 3.2 Giga-symbols/second through the Ka-band TWTA. Transmitter pre-compensation was enabled.

For each modulation type, the bit rate was selected such that a constant channel symbol rate of 3.2 Gsps was achieved. This led to an information bit rate of 5.7 Gbps for the lowestorder modulation tested, QPSK, and up to $20 \mathrm{Gbps}$ for the highest-order modulation tested, 128-QAM. For each waveform under test, the input power to the TWTA was set such that its average output power back-off (OBO) from saturation was approximately equal to the peak-to-average power of the waveform in an ideal undistorted state. Figure 5 plots BER vs. $\mathrm{E}_{\mathrm{b}} / \mathrm{N}_{0}$ for each of the modulation types tested with the DVB-S2 LDPC 9/10 codec. The recovered signal constellation diagrams for the six waveforms, when precompensation as well as adaptive equalization are applied, are shown in Figure 6. Notice that the symbols are distinct, which indicates excellent compensation for system non-linearity. 


\section{Space-To-Earth RF Link Budget Analysis}

The above results are included in a RF link budget analysis, which besides other parameters takes into account the TWTA output power, spacecraft antenna diameter, available spectrum or bandwidth, atmospheric attenuation, range, ground antenna diameter and $\mathrm{G} / \mathrm{T}$ ratio. The analysis generates the achievable data rates for NASA's four data links discussed in Section I. Table I compares the achievable data rates with the current state-of-practice. The data rate improvement factor in all cases is an order of magnitude or greater $(>10 \mathrm{X})$. Commercial Earth imaging satellites transmit $800 \mathrm{Mbps}$ from LEO, using two orthogonally polarized $400 \mathrm{Mbps}$ channels, at X-band. If the next generation Earth imaging satellites migrated to Ka-band, the achievable data rate and improvement factor per polarization would be as high as $2.8 \mathrm{Gbps}$ and 7X, respectively, using our advanced modem technology.

TABLE I.-CURRENT STATE-OF-PRACTICE, ACHIEVABLE DATA RATE AND IMPROVEMENT FACTOR FOR NASA'S FOUR DATA LINKS IN SECTION I

\begin{tabular}{|c|c|c|c|}
\hline \multicolumn{4}{|c|}{ Current state-of-practice } \\
\hline $\begin{array}{c}\text { Type of link and } \\
\text { distance }\end{array}$ & $\begin{array}{c}\text { Center frequency, } \\
\mathrm{GHz}\end{array}$ & $\begin{array}{c}\text { TWTA P } \\
\mathrm{W}\end{array}$ & $\begin{array}{c}\text { Data rate, } \\
\text { Mbps }\end{array}$ \\
\hline $\begin{array}{c}\text { LEO, } \\
700 \mathrm{~km}\end{array}$ & X-band, 8.45 & 20 & 150 \\
\hline $\begin{array}{c}\text { LRS, } \\
384000 \mathrm{~km}\end{array}$ & K-band, 25.65 & 40 & 100 \\
\hline $\begin{array}{c}\text { L2, } \\
\text { million km }\end{array}$ & K-band, 25.9 & 58 & 28 \\
\hline $\begin{array}{c}\text { DS, } \\
1 \mathrm{AU}\end{array}$ & $\begin{array}{c}\text { X- and Ka-band, } \\
8.45 \text { and 32.05 }\end{array}$ & $\begin{array}{c}100 \text { (X-band) and } \\
35 \text { (Ka-band) }\end{array}$ & 6 \\
\hline \multicolumn{4}{|}{} \\
\hline
\end{tabular}

\begin{tabular}{|c|c|c|c|}
\hline \multicolumn{4}{|c|}{ 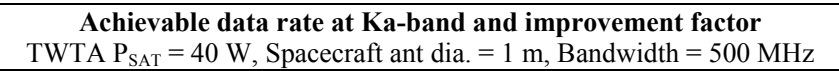 } \\
\hline $\begin{array}{l}\text { Type of link and } \\
\text { distance }\end{array}$ & $\begin{array}{l}\text { Ground antenna dia. } \\
\text { (m) and elevation } \\
\text { angle }\end{array}$ & $\begin{array}{l}\text { Achievable } \\
\text { data rate, } \\
\text { Gbps }\end{array}$ & $\begin{array}{l}\text { Improvement } \\
\text { factor }\end{array}$ \\
\hline $\begin{array}{l}\text { LEO, } \\
700 \mathrm{~km}\end{array}$ & $2,5^{\circ}$ & 2.8 & $19 \mathrm{X}$ \\
\hline $\begin{array}{c}\text { LRS, } \\
384000 \mathrm{~km}\end{array}$ & $\begin{array}{c}18.3,10^{\circ} \\
(\mathrm{G} / \mathrm{T}>46.5 \mathrm{~dB} / \mathrm{K})\end{array}$ & 0.95 & $10 \mathrm{X}$ \\
\hline \multicolumn{4}{|c|}{$\begin{array}{c}\text { TWTA P } \mathrm{P}_{\mathrm{SAT}}=100 \mathrm{~W}, \text { Spacecraft ant dia. }=4-5 \mathrm{~m}, \\
\text { Bandwidth }=300 \mathrm{MHz}\end{array}$} \\
\hline $\begin{array}{l}\mathbf{L 2} \\
1.5 \text { million } \mathrm{km}\end{array}$ & $\begin{array}{c}18.3,10^{\circ} \\
(\mathrm{G} / \mathrm{T}>46.5 \mathrm{~dB} / \mathrm{K})\end{array}$ & 0.95 & $34 \mathrm{X}$ \\
\hline $\begin{array}{c}\text { DS, } \\
1 \mathrm{AU}\end{array}$ & $\begin{array}{c}34,10^{\circ} \\
(\mathrm{G} / \mathrm{T}>60 \mathrm{~dB} / \mathrm{K})\end{array}$ & 0.08 & $13 \mathrm{X}$ \\
\hline
\end{tabular}

\section{Conclusions and Discussions}

The paper presents the first ever research and experimental results regarding the combination of a software-defined multiGbps modem and a broadband high power space amplifier when tested with the extended industry standard DVB-S2 and LDPC rate 9/10 FEC codec. The modem and the TWTA together enabled an unprecedented data throughput of $20 \mathrm{Gbps}$ with low BER of $10^{-9}$. The presented results include a plot of the received waveform constellation, BER vs. $E_{b} / N_{0}$ and implementation loss for each of the modulation types tested. The above results when included in a RF link budget analysis show that NASA's payload data rate can be increased by at least an order of magnitude ( $>10 \mathrm{X})$ over current state-ofpractice. Finally, the above demonstration shows that a Kaband transmitter with data rate at $20 \mathrm{Gbps}$ is achievable and the link capacity is limited only by the spacecraft antenna EIRP, ground receiver $\mathrm{G} / \mathrm{T}$, range, and available spectrum or bandwidth.

\section{References}

1. J. Schier, Space Communications and Navigation Integrated Network Architecture Definition Document Volume 1: Executive Summary, Jan 2010, NASA Headquarters, Washington, D.C.

2. Earth Science and Applications from Space: National Imperatives for the Next Decade and Beyond, p. 96, p. 113 , p. 356, The National Academies Press, Washington, D.C., 2007.

3. 2010 IEEE MTT-S IMS Workshop (WMF) notes entitled "High Efficiency, High Power Microwave Amplifiers for High Data Rate Space Communications," Anaheim, CA, May 24, 2010.

4. D.G. Landon, J.Y. Sun, J.S. Winn, S. Laraway, W.K. McIntire, J.L. Metz, F.J. Smith, R.N. Simons, and E.G. Wintucky, "Demonstration of Software-Defined MultiGbps Modem Technology for Ka-Band Satellite Communications," GOMACTech-11, Orlando, FL, March 21-24, 2011.

5. R.N. Simons, J.D. Wilson and D.A. Force, "High Power and Efficiency Space Traveling-Wave Tube Amplifiers With Reduced Size and Mass for NASA Missions," 2008 IEEE MTT-S IMS Digest, pp. 319-322, Atlanta, GA, June $15-20,2008$. 
6. R.N. Simons, D.A. Force, P.C. Spitsen, W.L. Menninger, N.R. Robbins, D.R. Dibb, and P.C. Todd, "High-Efficiency K-Band Space Traveling-Wave Tube Amplifier for NearEarth High Data Rate Communications," 2010 IEEE MTTS IMS Digest, pp. 1400-1403, Anaheim, CA, May 23-28, 2010.

7. Digital Video Broadcasting (DVB); Second generation framing structure, channel coding and modulation systems for Broadcasting, Interactive Services, News Gathering and other broadband satellite applications, ETSI EN 302307 V1.1.1 (2005-03), 650 Route des Lucioles F-06921 Sophia Antipolis Cedex, France.
8. L. Giugno, M. Luise, and V. Lottici, "Adaptive Pre- and Post-compensation of Nonlinear Distortions for High-level Data Modulations," IEEE Trans. Wireless Commun., vol. 3, no. 5, pp. 1490-1495, Sept 2004.

9. S. ten Brink, R. Mahadevappa, "Implementation Aspects of High-Speed Wireless LAN Systems," Signals, Systems and Computers, 2004. Thirty-Eighth Asilomar Conf., vol. 1, pp. 789-793, Nov 7-10, 2004.

10. G. Marsaglia; W. Tsang, "The Ziggurat Method for Generating Random Variables," Journal of Statistical Software, vol. 5, issue 8, Oct 2000. 


\begin{tabular}{|c|c|c|}
\hline \multicolumn{2}{|c|}{ REPORT DOCUMENTATION PAGE } & $\begin{array}{l}\text { Form Approved } \\
\text { OMB No. 0704-0188 }\end{array}$ \\
\hline \multicolumn{3}{|c|}{$\begin{array}{l}\text { The public reporting burden for this collection of information is estimated to average } 1 \text { hour per response, including the time for reviewing instructions, searching existing data sources, gathering and maintaining the } \\
\text { data needed, and completing and reviewing the collection of information. Send comments regarding this burden estimate or any other aspect of this collection of information, including suggestions for reducing this } \\
\text { burden, to Department of Defense, Washington Headquarters Services, Directorate for Information Operations and Reports (0704-0188), } 1215 \text { Jefferson Davis Highway, Suite } 1204 \text {, Arlington, VA } 22202-4302 \text {. } \\
\text { bespondents should be aware that notwithstanding any other provision of law, no person shall be subject to any penalty for failing to comply with a collection of information if it does not display a currently valid OMB } \\
\text { control number. } \\
\text { PLEASE DO NOT RETURN YOUR FORM TO THE ABOVE ADDRESS. }\end{array}$} \\
\hline $\begin{array}{l}\text { 1. REPORT DATE (DD-MM-YYYY) } \\
01-04-2011\end{array}$ & $\begin{array}{l}\text { 2. REPORT TYPE } \\
\text { Technical Memorandum }\end{array}$ & 3. DATES COVERED (From - To) \\
\hline \multirow{3}{*}{\multicolumn{2}{|c|}{$\begin{array}{l}\text { 4. TITLE AND SUBTITLE } \\
\text { Demonstration of Multi-Gbps Data Rates at Ka-Band Using Software-Defined Modem and } \\
\text { Broadband High Power Amplifier for Space Communications }\end{array}$}} & 5a. CONTRACT NUMBER \\
\hline & & 5b. GRANT NUMBER \\
\hline & & 5c. PROGRAM ELEMENT NUMBER \\
\hline \multirow{3}{*}{\multicolumn{2}{|c|}{$\begin{array}{l}\text { 6. AUTHOR(S) } \\
\text { Simons, Rainee, N.; Wintucky, Edwin, G.; Landon, David, G.; Sun, Jun, Y.; Winn, James, S.; } \\
\text { Laraway, Stephen; McIntire, William, K.; Metz, John, L.; Smith, Francis, J. }\end{array}$}} & 5d. PROJECT NUMBER \\
\hline & & 5e. TASK NUMBER \\
\hline & & $\begin{array}{l}\text { 5f. WORK UNIT NUMBER } \\
\text { WBS 432938.11.01.03.02.02.15 }\end{array}$ \\
\hline \multicolumn{2}{|c|}{$\begin{array}{l}\text { 7. PERFORMING ORGANIZATION NAME(S) AND ADDRESS(ES) } \\
\text { National Aeronautics and Space Administration } \\
\text { John H. Glenn Research Center at Lewis Field } \\
\text { Cleveland, Ohio 44135-3191 }\end{array}$} & $\begin{array}{l}\text { 8. PERFORMING ORGANIZATION } \\
\text { REPORT NUMBER } \\
\text { E-17733 }\end{array}$ \\
\hline \multirow{2}{*}{\multicolumn{2}{|c|}{$\begin{array}{l}\text { 9. SPONSORING/MONITORING AGENCY NAME(S) AND ADDRESS(ES) } \\
\text { National Aeronautics and Space Administration } \\
\text { Washington, DC 20546-0001 }\end{array}$}} & $\begin{array}{l}\text { 10. SPONSORING/MONITOR'S } \\
\text { ACRONYM(S) } \\
\text { NASA }\end{array}$ \\
\hline & & $\begin{array}{l}\text { 11. SPONSORING/MONITORING } \\
\text { REPORT NUMBER } \\
\text { NASA/TM-2011-217035 }\end{array}$ \\
\hline \multicolumn{3}{|c|}{$\begin{array}{l}\text { 12. DISTRIBUTION/AVAILABILITY STATEMENT } \\
\text { Unclassified-Unlimited } \\
\text { Subject Category: } 17 \\
\text { Available electronically at http://www.sti.nasa.gov } \\
\text { This publication is available from the NASA Center for AeroSpace Information, 443-757-5802 }\end{array}$} \\
\hline
\end{tabular}

\section{ABSTRACT}

The paper presents the first ever research and experimental results regarding the combination of a software-defined multi-Gbps modem and a broadband high power space amplifier when tested with an extended form of the industry standard DVB-S2 and LDPC rate 9/10 FEC codec. The modem supports waveforms including QPSK, 8-PSK, 16-APSK, 32-APSK, 64-APSK, and 128-QAM. The broadband high power amplifier is a space qualified traveling-wave tube (TWT), which has a passband greater than $3 \mathrm{GHz}$ at $33 \mathrm{GHz}$, output power of 200 W and efficiency greater than 60 percent. The modem and the TWTA together enabled an unprecedented data rate at 20 Gbps with low BER of $10^{-9}$. The presented results include a plot of the received waveform constellation, BER vs. Eb/N0 and implementation loss for each of the modulation types tested. The above results when included in an RF link budget analysis show that NASA's payload data rate can be increased by at least an order of magnitude ( $>10 \mathrm{X})$ over current state-of-practice, limited only by the spacecraft EIRP, ground receiver G/T, range, and available spectrum or bandwidth.

\section{SUBJECT TERMS}

Telecommunications; Transmitters; Deep Space Network; Space communication; Satellite communications; Microwave transmission; Microwave amplifiers; Microwave tubes; Power amplifiers; Power conditioning; Power efficiency; Traveling wave tubes

\begin{tabular}{|c|c|c|c|c|c|}
\hline \multicolumn{3}{|c|}{ 16. SECURITY CLASSIFICATION OF: } & \multirow{2}{*}{$\begin{array}{l}\text { 17. LIMITATION OF } \\
\text { ABSTRACT } \\
\text { UU }\end{array}$} & \multirow{2}{*}{$\begin{array}{l}\text { 18. NUMBER } \\
\text { OF } \\
\text { PAGES } \\
12\end{array}$} & \multirow{2}{*}{$\begin{array}{l}\text { 19a. NAME OF RESPONSIBLE PERSON } \\
\text { STI Help Desk (email:help@ } \text { sti.nasa.gov) } \\
\text { 19b. TELEPHONE NUMBER (include area code) } \\
\text { 443-757-5802 }\end{array}$} \\
\hline $\begin{array}{l}\text { a. REPORT } \\
U\end{array}$ & $\begin{array}{l}\text { b. ABSTRACT } \\
\mathrm{U}\end{array}$ & $\begin{array}{l}\text { c. THIS } \\
\text { PAGE } \\
\text { U }\end{array}$ & & & \\
\hline
\end{tabular}



